\title{
The Role of Indonesian Tax Reform in Boosting Export Performance of Manufacturing Sectors
}

\author{
Submitted 28/08/19, $1^{\text {st }}$ revision 19/09/19, $2^{\text {nd }}$ revision 11/10/19, accepted 19/11/19
}

\author{
Agus Sholikhan Yulianto ${ }^{1}$, Anis Chariri ${ }^{2}$
}

\begin{abstract}
:
Purpose: This study aims to develop and explore the regulation role of Indonesian tax reform (ITR) by referring to the tax incidences theory. This study, therefore, focuses on the potential forward and backward shifting impacted by the tax reform. ITR influences corporate capital expenditures, production capacity, and labor cost proportion to total production cost.

Design/methodology/approach: The study uses data from the manufacturing sector listed in the Indonesian capital market from 2004 to 2013. Data is analyzed using panel data regression and includes the common, fixed and random effect model.

Findings: This study reveals that ITR directly does not influence export performance nor indirectly through the forward shifting effect. On the other hand, ITR is effective in boosting Indonesian manufacturing export performance through the backward shifting. Capital expenditure furthermore plays a crucial factor in ITR success.

Originality/value: This study highlights that Indonesian export performance has increased followed the tax reformation.
\end{abstract}

Keywords: Tax reform, capital expenditure, production capacity, export performance.

JEL Codes: D24, H71, H72.

Paper type: Research article.

\footnotetext{
${ }^{1}$ Diponegoro University; Sultan Ageng Tirtayasa University, Indonesia, e-mail: agusresearch@untirta.ac.id

${ }^{2}$ Diponegoro University, Semarang, Indonesia.
} 


\section{Introduction}

Indonesian Tax Reform (ITR) 2008 has become a strategic policy in mitigating the adverse effect of global economic downturn during 2007-2008. The Indonesian government and the house of representatives carry out the tax reform through the passage of Income Tax Act 36/2008. The regulation also provides a special tax rate (5\% lower) for the eligible companies. The reason that encouraged the awarding of those tax facilities originated from consideration on the potential negative influence of the tax on business competitiveness.

Tax incidences theory explains that the tax potentially creates distortions in economic choices and generates inefficiencies in economic policy (Nicodeme, 2009). Mieszkowski (1969) and Nicodeme (2009) stated that taxes affect level of demand and worker effectiveness directly. The burdens could be shifted back to the employees or forward to the consumer (Harberger, 2008; 1962). Tax may reduce the competitiveness of the selling price.

The previous study (Amir et al., 2013; Hageman et al., 2015) investigated the impact of tax on capital expenditure through the lens of a macroeconomics perspective. Amir et al. (2013) documented the positive influence of ITR 2008 (includes corporate income tax and personal income tax change) on the macroeconomic indicators. Meanwhile, Hageman et al. (2015) revealed the negative impact of sales and the usetax on capital and labor expenditures.

The study focuses on the relationship between ITR 2008 and export performance of the manufacturing sectors through backward and forward effect scenario. ITR 2008 may enhance export performance through the improvement in production capacity and labor expenditure. The study is still incorporating the tax effect on the labor expenditure.

\section{Literature Review}

\subsection{ITR 2008 and Export Performance}

Devereux and Griffith (1998) stated that in an open economic system, goods and capital flows were made possible with the advancement of information technology (banking and finance) and transportation. According to Derashid and Zhang (2003), various benefits including tax benefits provide strategic values to improve economic and social objectives including protecting the domestic sector from foreign competition, increasing export performance, enhancing competitiveness and encouraging development of high technology.

Taxes affect incentives of employees, savings, rates and investment patterns (Mieszkowski, 1969). The real response to tax reform may occur in the form of the changes in production inputs, production scheduling, and production location 
determination (Slemrod, 1995). Tax reform is an important instrument used by government to improve economic competitiveness. Malaysian government demonstrated the strategic role of tax rate tariffs on export performance by providing a $100 \%$ taxable income reduction incentive to ownership of an export-oriented foreign manufacturing firm (Derashid and Zhang, 2003). Thus, the research hypothesis is:

H1: ITR positively influences export performance.

\subsection{ITR 2008 and Capital Expenditure}

Taxation regulation potentially changes firm's financial decision because of the change in the cash outflow for paying income tax. ITR 2008 provided an opportunity for companies to get additional tax saving. The reduction of corporate income tax rate allows lower cash outflow for paying tax. Therefore, the lowered tax rate potentially enables companies to strengthen their payout policy toward productive activities.

Hageman et al. (2015) documented that sales and use-tax negatively influence capital and labor expenditures. Consideration of payout policy for capital expenditure has a higher relevance with the underlying motivation of ITR 2008 than paying a dividend. Expenditures on machinery, production facilities, and inventories enable firms to avoid shortage capacity. ITR 2008 might encourage the increase of capital expenditures for the production facilities and another illiquid asset under the assumption of insufficient idle capacity. Thus, the research hypothesis is:

\section{H2: ITR positively influences capital expenditure.}

\subsection{ITR 2008 and Production Capacity}

The potential increase in production capacity after ITR 2008 may occur due to the absorption of tax saving into production activities and also from the foreign capital inflow. Reduction in the corporate income tax rate provided a saving on cash outflow. The higher production capacity provides an opportunity for companies to increase the sales volume and generate more cash inflow. On the other hand, reduction in corporate income tax rate also provides lower domestic marginal cost of production factors under the assumption of high input price elasticity. Poterba (1996) proved that tax is a mark-up factor that reduces output price competitiveness. Reduction in the corporate income tax rate may result in the decreased production inputs cost by assuming that all inputs are available domestically.

Devereux and Griffith (1998) suggested that consideration of the marginal cost of production factors were the most important in production base location determination. Multinational corporations tend to relocate their production base to countries with much cheaper input prices (Yu et al., 2007). According to O'Brien and Scally (2012), various improvement measures of cost competitiveness can help maintaining a strong network of foreign direct investment, forecasting future export performance, and 
creation of high-level skilled jobs. Both cash flows, saving and foreign capital inflows will directly flow into production activity. Thus, the research hypothesis is:

H3: ITR 2008 positively influences production capacity.

\subsection{Capital Expenditure and Production Capacity}

Acquisition of machinery, production facilities, and other fixed assets are crucial in improving production capacity. Jiang (2017) argued that expenditures for equipment maintenance showed a positive relationship with a substantial fraction of output and new investment. The decision to invest in the long term asset is assumed supported by future sustainable cash flow expectation.

Capital expenditures usually involve enormous financial sources and long useful life (Liao et al., 2016). Consideration of future cash flow for a long term perspective is a critical judgment in capital expenditures decision. On the other hand, the cash flow generating activities beginning from the production activity and terminated in the sales function. Investment in the long and short term production factor is the crucial factor in maintaining and upgrading the production of line capacity. The fluency of the sales function relies on the availability of the finished product, especially during the increasing demand period. Capability in absorbing capital expenditures into productive activity is prerequisite for the effectiveness of the expansion. Hence, intensive capital expenditure will boost the increase of production capacity. Thus, the research hypothesis is:

H4: Capital expenditure positively influences production capacity.

\subsection{Capital Expenditure and Export Performance}

Capital expenditures imply a strategic expansion by upgrading and improving operational capability, including the production capacity. According to Rust et al. (2002), companies run the expansion orientation to get better performance than those which apply cost reduction orientation. Capital expenditures provide a bigger capacity for company to enhance its economies of scale.

Investment is a strategic policy to capture positive or negative shock, especially during crises. Investment in a long term fixed asset implies a positive future expectation. Capital expenditures may convey information about projected earnings (Kerstein, 1995). The prospect of domestic and foreign demand constitutes valuable information underliing the expenditures decision. Therefore, investment in production facilities and other fixed assets allows company to convert the potential prospect into effective domestic and export sales. Thus, the research hypothesis is:

H5: Capital expenditure positively influences export performance. 


\subsection{Production Capacity and Export Performance}

The relationship between production capacity and export performance emerges in two channels. Firstly, production capacity increase may indicate the shift of foreign manufacturing base to domestic. The domestic corporate income tax rate reduction has a potential power in motivating the multinational firms to shift their production as well as the sales base domestically. The shift will increase the domestic production capacity intended both for domestic and export activities. Hence, the production capacity improvement results in the export performance increase which indicates the change in the international distortion level. Secondly, the demand for export drives the production capacity to higher level. The sufficient finished good availability is a requirement to be able to meet export demand. The capability in providing output constitutes one of the pillars in fulfilling the open gaps between demand and supply. According to Liu and Lu (2015) a firm's capability to invest in the fixed asset determine the increase of export propensity. Thus, the research hypothesis is:

\section{H6: Production capacity positively influences export performance.}

\section{Research Methodology}

This study uses financial report data collected from manufacturing firms listed in Indonesian Capital Market. The unit analysis is at the corporate level for a longitudinal time horizon involved 10 years period from 2004 to 2013. The sample is 590 manufacturing firm years (Table 1). The study applies panel data regression for analyzing data and includes common effect, fixed effect, and random effect models.

\section{Table 1. Sample Selection}

\begin{tabular}{|l|l|l|}
\hline Criteria & \multicolumn{2}{l|}{ Quantity } \\
\hline Manufacturing company (2004-2013) & 1.239 & firm years \\
\hline Not listing completely (2004-2013) & $(89)$ & firm years \\
\hline Not Report export activity (2004-2013) & $(436)$ & firm years \\
\hline Not Reporting export activity completely & $(124)$ & firm years \\
\hline Sample & 590 & firm years \\
\hline
\end{tabular}

\section{Results}

\subsection{Descriptive Analysis}

EXPORT, CAPEX, sales, and production capacity in the average increased from 2004 to 2013. Nonetheless, all variables showed a declining movement in 2009. The declining trends imply the apparent impact of global economic crises during 2009. However, from 2010 to the years afterward, all variable showed the rebound trend. The average of all variable proportion to sales tends to be constant for the observed period except margin to sales. Increase in the average domestic sales dominated the increase in sales average. The tripled increase in export average had to be achieved by 
ten years long, reflected the weak role of the export sales in propping the incomegenerating activities.

MRG_to_SALES on average showed movement since 2007 after increased sharply from 2004 to 2007. On the other hand, average COGM_to_SALES showed a declining trend from 2004 to 2013. The increase in of MRG_to_SALES might be implied the increased level of forwarding shifting behavior during the period of 2004 to 2013. However, the decrease in the COGM_to_SALES indicated that forward shifting was not the dominant factor of increasing the trend of MRG_to_SALES.

Figure 1. Descriptive Statistic

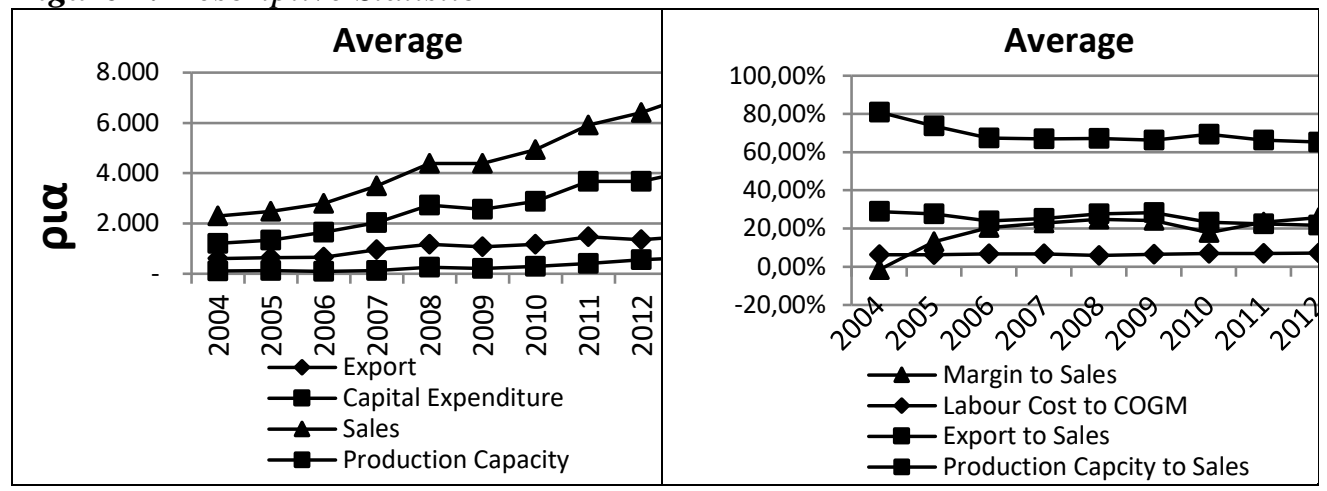

COGM_to_SALES was the supporting factor of the increase in the MRG_to_SALES trend. Our conclusion that forward shifting was not the prevailed effect in the selling price determination also emerged from panel data regression analysis that did not show any significant influence of ITR 2008 on the margin portion to sales.

\subsection{Panel Data Regression Analysis}

ITR 2008 negatively influences export performance. This result indicates that the negative direct impact of tax reform on export performance is almost zero. On the other hand, this analysis shows that ITR 2008 is effective in influencing export performance indirectly through a backward shifting effect scenario. The scheme begins with the significant positive influence of tax reform on capital expenditures. Capital expenditure shows a significant positive effect on production capacity. Finally, the increase in production capacity boosts export performance significantly.

The findings suggest that capital expenditure holds a crucial role in the success of the backward shifting effect scenario played by ITR 2008 in boosting export performance. However, the negative influence of capital expenditure on export performance implies that capital expenditures do not automatically increase the export. The analysis suggests that absorption of capital expenditures into production facilities and any supporting asset is the prerequisite for the corporates in acquiring additional capacity both in production and in delivering service to its customer. 
This investigation has no effect of ITR 2008 on export performance through the forward effect scenario. The analysis does not show a significant influence of ITR 2008 on the export performance directly or through the proportion of gross margin to sales. Improving manufacturing export performance through a forward shifting effect is not appropriate. However, this study shows that the backward shifting effect flows into the forward shifting process. The proportion of labor expense in production cost influences gross margin portion to sales positively. The increase in the use of labor implies the improvement of conversion activity.

Table 2. Pearson Correlation Analysis

\begin{tabular}{|c|c|c|c|c|c|c|c|c|}
\hline Variables & Parameters & ITR_2008 & EXPORT & CAPEX & COGM & $\begin{array}{l}\text { MRG_ } \\
\text { to_- } \\
\text { SALES }\end{array}$ & $\begin{array}{l}\mathrm{MTL}_{-} \\
\text {to_- } \\
\text { COGM }\end{array}$ & $\begin{array}{l}\text { LBR_ } \\
\text { to_- } \\
\text { COGM }\end{array}$ \\
\hline \multirow[t]{3}{*}{ EXPORT } & Correlation & $100 *$ & & & & & & \\
\hline & Sig. (2-tailed) & 0,015 & & & & & & \\
\hline & $\mathrm{N}$ & 590 & & & & & & \\
\hline \multirow[t]{3}{*}{ CAPEX } & Correlation & ,198** & ,484** & & & & & \\
\hline & Sig. (2-tailed) & 0 & 0 & & & & & \\
\hline & $\mathrm{N}$ & 590 & 590 & & & & & \\
\hline \multirow[t]{3}{*}{ COGM } & Correlation &, $172 * *$ & ,710** &, $802 * *$ & & & & \\
\hline & Sig. (2-tailed) & 0 & 0 & 0 & & & & \\
\hline & $\mathrm{N}$ & 590 & 590 & 590 & & & & \\
\hline \multirow[t]{3}{*}{ MRG_to_SALES } & Correlation & 0,035 &,$- 082 *$ & 0,042 & $-0,052$ & & & \\
\hline & Sig. (2-tailed) & 0,393 & 0,046 & 0,308 & 0,206 & & & \\
\hline & $\mathrm{N}$ & 590 & 590 & 590 & 590 & & & \\
\hline \multirow[t]{3}{*}{ MTL_to_COGM } & Correlation & 0,028 & 0,067 &,$- 107 * *$ & 0,041 &,$- 155 * *$ & & \\
\hline & Sig. (2-tailed) & 0,49 & 0,105 & 0,009 & 0,326 & 0 & & \\
\hline & $\mathrm{N}$ & 590 & 590 & 590 & 590 & 590 & & \\
\hline \multirow[t]{3}{*}{ LBR_to_COGM } & Correlation & 0,053 &,$- 117 * *$ & 0,012 &,$- 131 * *$ &, $175 * *$ &,$- 356^{* *}$ & \\
\hline & Sig. (2-tailed) & 0,2 & 0,004 & 0,774 & 0,001 & 0 & 0 & \\
\hline & $\mathrm{N}$ & 590 & 590 & 590 & 590 & 590 & 590 & \\
\hline \multirow[t]{3}{*}{ FOHtoCOGM } & Correlation & $-0,033$ & $-0,038$ &, $124 * *$ & 0,001 &, $116^{* *}$ &,$- 951 * *$ &, $142 * *$ \\
\hline & Sig. (2-tailed) & 0,425 & 0,352 & 0,003 & 0,987 & 0,005 & 0 & 0,001 \\
\hline & $\mathrm{N}$ & 590 & 590 & 590 & 590 & 590 & 590 & 590 \\
\hline
\end{tabular}

* Correlation is significant at the 0.05 level; ** Correlation is significant at the 0.01 level

Source: Secondary data from Indonesian Capital Market Directory

Table 3. Panel Data Regression Analysis

\begin{tabular}{|c|c|c|c|c|c|c|c|}
\hline \multirow[b]{2}{*}{\begin{tabular}{|l} 
Exogenous \\
Variables/Test
\end{tabular}} & \multicolumn{7}{|c|}{ Endogenous Variable } \\
\hline & CAPEX & COGM & $\begin{array}{l}\text { LBR } \\
\text { to- } \\
\text { COGM }\end{array}$ & $\begin{array}{l}\text { MTL }_{-} \\
\text {to }_{-} \\
\text {COGM }\end{array}$ & $\begin{array}{l}\mathrm{FOH}_{-} \\
\text {to- }_{-} \\
\text {COGM }\end{array}$ & $\begin{array}{l}\text { MRG } \\
\text { to- } \\
\text { SALES }\end{array}$ & EXPORT \\
\hline \multirow[t]{2}{*}{ Const } & $-3,41, \mathrm{E}+11$ & $5,98 \mathrm{E}+11$ & $6,75 \mathrm{E}-02$ & 0,6529 & 0,2796 & 0,1638 & $-1,26 \mathrm{E}+11$ \\
\hline & $k 0,0001^{* * * *}$ & 0,2245 & $<0,0001^{* * * *}$ & $k 0,0001^{* * * * *}$ & $k 0,0001^{* * * *}$ & k0,0001**** & $7,06 \mathrm{E}-01$ \\
\hline \multirow[t]{2}{*}{ ITR 2008} & $2,87, \mathrm{E}+11$ & $2,63 \mathrm{E}+11$ & $8,85 \mathrm{E}-03$ & 0,0158 & $-0,0247$ & 0,0049 & $-5,53 \mathrm{E}+10$ \\
\hline & $<0,0001 * * *$ & 0,2245 & $0,0225^{* *}$ & 0,3306 & $0,0959^{*}$ & 0,7206 & $7,00 \mathrm{E}-01$ \\
\hline \multirow[t]{2}{*}{ CAPEX } & & $4,73 \mathrm{E}+00$ & $0,00 \mathrm{E}+00$ & 0,0000 & 0,0000 & 0,0000 & $-8,62 \mathrm{E}-01$ \\
\hline & & k0,0001**** & $<0,0001^{* * * *}$ & $<0,0001^{* * * *}$ & $<0,0001^{* * * *}$ & $0,0712^{*}$ & $<0,0001^{* * * *}$ \\
\hline \multirow[t]{2}{*}{ COGM } & & & $0,00 \mathrm{E}+00$ & 0,0000 & 0,0000 & 0,0000 & $5,11 \mathrm{E}-01$ \\
\hline & & & $<0,0001^{* * *}$ & $<0,0001^{* * *}$ & $<0,0001^{* * *}$ & 0,4027 & $<0,0001^{* * *}$ \\
\hline \multirow[t]{2}{*}{ LBR_to_COGM } & & & & & & 0,5840 & $2,03 \mathrm{E}+11$ \\
\hline & & & & & & $0,0001 * * *$ & $9,00 \mathrm{E}-01$ \\
\hline \multirow[t]{6}{*}{ MRG_to_SALES } & & & & & & & $-3,92 \mathrm{E}+11$ \\
\hline & & & & & & & $3,98 \mathrm{E}-01$ \\
\hline & & & & & & 0,192201 & 0,568934 \\
\hline & & & & & & 71,518 & 10,59984 \\
\hline & & & & & & $k_{0,0001}$ & $<0,0001^{* * *}$ \\
\hline & & & & & & 1,991170 & 1,777775 \\
\hline Testing model & Random Effect & Random Effect & Random Effect & Random Effect & Random Effect & Fixed Effect & Fixed Effect \\
\hline
\end{tabular}




\section{Discussion}

This study confirms the power of tax incidence theory in explaining the shift of economic behavior impacted by a tax regulation. The tax incidence theory assumption of economic distortion exhibited sound judgment. The distortion existed when personal(s) or business entity(s) failed to allocate its resources into productive activities. Then resource allocation adjustment indicated the existence of such distortion. As economic distortion was the effect of tax imposition then alteration in tax regulation (tax rate change) potentially alter the distortion. Increase in capital expenditure following the corporate income tax rate change indicated the economic distortion mitigation. This study provides evidence that the alteration of the tax rate shows power in stirring resource allocation toward productive activities.

The indirect influence of tax reform on export performance indicates the role of economic distortions in shaping the business' competitiveness. Capital expenditures role in the success of tax reform depicts how tax rate change as the representation of the manipulation of economic distortion alters the choice in the business activity. Increase in economic activity due to the increase in capital expenditure is an indication that the reduction of economic distortion is a crucial factor in improving economic competitiveness. Increase in capital expenditure after the change of the tax rate indicates that the policy was effective in reducing the economic distortion.

The statistical analysis indicates that ITR 2008 does not show a direct effect on export performance. The essence of the direct influence is the price competitiveness role as the determinant of the performance. However, the analysis shows that the export performance of Indonesian manufacturing sectors is not the function of price competitiveness. According to Harberger (2008) selling price of a tradable good is the function of demand and supply mechanism. By assuming the low price elasticity, the producer cannot expect to raise demand sharply by shifting the supply curve to the right (reduce the selling price) due to the tax burden reduction. Hence, forward shifting is not the right channel of the export performance improvement. The change in the corporate income tax rate did not increase Indonesian manufacturing sectors competitiveness automatically.

The analysis shows that ITR 2008 influences the export performance indirectly through the role of capital expenditure and an increase in production capacity. Indonesian manufacturing firm's export performance was the function of production capacity. Indonesian manufacturing firms' capability to fill foreign demand is the function of their production capacity. This finding indicates that the mitigated economic distortion will result in the performance increase when the firms are able to exploit it in productive activity.

The analysis also shows that potential tax saving provided by ITR 2008 does not have a direct effect on the production capacity. This result indicates that sufficient idle capacity which is able to absorb the resource provided by the tax reform into 
productive activity directly was not available. On the other hand, the increase in production capacity is the function of the production facility. The indirect influence of ITR 2008 on production capacity through the capital expenditures indicates that Indonesian manufacturing company entailed additional capability to increase its production capacity.

The findings imply that the tax reform was effective in alleviating the restrictiveness of Indonesian manufacturing production capacity. This limitation prevents the quick response of Indonesian manufacturing sectors to increase their production capacity for an unexpected opportunity. The restrictiveness implies that the firms entail essential supporting factors to improve their production capacity. Capital expenditures allow the firms to raise production activity both in quality and quantity.

This study broadened the comprehension of the tax incidence theory, especially the sequential process of the economic distortion flow. Capital expenditures play a crucial role in flowing economic distortion into profitable business activities. Understanding the sequence processes provided the logical basis for problem-solving related to the tax regulation effect on business competitiveness.

\section{Conclusion}

This study shows that ITR 2008 is effective in increasing Indonesian manufacturing export performance through the backward shifting channel. This study proves that Indonesian export performance increased followed the tax reformation. The increase of export performance after ITR 2008 indicates that tax burden creates economic distortions and tax rate manipulation become an effective instrument for managing the distortion level. The crucial role of capital expenditures in facilitating ITR 2008 effectiveness indicates the alteration of capital distortion impacted by ITR 2008.

Notwithstanding, this study contains several weaknesses, especially related to the research design. Archival research limited the data analysis to the published financial data only. The proxy of forwarding shifting variable will be more representative if the unit price of output data is available at each corporate level.

\section{References:}

Amir, H., Asafu-Adjaye, J., Ducpham, T. 2013. The impact of the Indonesian income tax reform: A CGE analysis. Econ. Model. 31, 492-501.

Derashid, C., Zhang, H. 2003. Effective Tax Rates and The Industrial Policy Hypothesis: Evidence from Malaysia. J. Int. Accounting, Audit. Tax., 12, 45-62.

Devereux, M.P., Griffith, R. 1998. Taxes and The Location of Production: Evidence From a Panel of US Multinationals. J. Public Econ., 68, 335-367.

Hageman, A., Bobek, D., Luna, L. 2015. The Influence of State Sales and Use Taxes on Manufacturers' Capital Expenditures and Employment. Public Financ. Rev., 43, 458484. 
Harberger, A.C. 2008. The Incidence of the Corporation Income Tax Revisited. Natl. Tax J., 41, 303-312.

Harberger, A.C. 1962. The Incidence of Corporate Income Tax. J. Polit. Econ. 70, 215-240.

Jiang, D., 2017. Indeterminacy, Capital Maintenance Expenditures, and the Business Cycle. Econ. Model., 61, 432-438.

Kerstein, J. 1995. Incremental Information Content of Capital Expenditures. Account. Rev., $70,513-526$.

Liao, L.K., Lin, Y.M., Lin, T.W. 2016. Non-Financial Performance in Product Market and Capital Expenditure. J. Bus. Res., 69, 2151-2159.

Liu, Q., Lu, Y. 2015. Firm Investment and Exporting : Evidence from China's Value-Added Tax Reform. J. Int. Econ., 97, 392-403.

Mieszkowski, B.P. 1969. Tax Incidence Theory: The Effects of Taxes on the Distribution of Income. J. Econ. Lit., 7, 1103-1124.

Nicodeme, G. 2009. Corporate Income Tax and Economic Distortion. Taxation Paper.

O'Brien, D.O., Scally, J. 2012. Cost Competitiveness and Export Performance of the Irish Economy. Q. Bull., 3, 86-102.

Poterba, J.M. 1996. Changes in State and Local Sales Taxes Retail Price Reactions to Changes in State and Local Sales Taxes. Natl. Tax J., 49, 165-176.

Rust, R.T., Moorman, C., Dickson, P.R. 2002. Getting Return on Quality: Revenue Cost or Both ? Reduction, Expansion. J. Mark., 66, 7-24.

Slemrod, J. 1995. Income Creation or Income Shifting? Behavioral Responses to the Tax Reform Act of 1986. Am. Econ. Rev., 85, 175-180.

Yu, C., Chang, T., Fan, C. 2007. FDI Timing : Entry Cost Subsidy Versus Tax Rate Reduction. Econ. Model., 24, 262-271. 